\title{
A Case of Immune Thrombocytopenic Purpura Associated with Preexisting Ulcerative Colitis Treated with Colectomy and Splenectomy
}

\author{
Jee Hye Kwon, Changhyun Lee ${ }^{1}$, Ji Min Choi, Yoo Min Han, Young Hoon Choi, June Young Lee, \\ Hyuk Yoon ${ }^{2}$, Jaeyoung Chun, Kyu Joo Park ${ }^{3}$, Jong Pil Im, Sang Gyun Kim, Joo Sung Kim, Hyun Chae Jung \\ Department of Internal Medicine and Liver Research Institute, Seoul National University College of Medicine, Department of Internal Medicine \\ and Healthcare Research Institute, Healthcare System Gangnam Center, Seoul National University Hospital, Seoul', Department of Internal \\ Medicine, Seoul National University Bundang Hospital, Seongnam², Department of Surgery, Seoul National University College of Medicine, \\ Seoul ${ }^{3}$, Korea
}

Ulcerative colitis is a chronic inflammatory bowel disease of unknown etiology, associated with extraintestinal manifestations, including the rarely reported immune thrombocytopenic purpura. Here, we present a case of immune thrombocytopenic purpura associated with preexisting ulcerative colitis. The patient was diagnosed with ulcerative colitis 13 years ago. Two years after diagnosis, he presented with hematochezia and active ulcerative colitis. Despite steroid use, the platelet count gradually decreased to $21,000 / \mathrm{mm}^{3}$. Hematochezia and the platelet count recovered after the administration of cyclosporine, and ulcerative colitis was in near complete remission for 11 years. However, the patient was re-admitted for hematochezia and thrombocytopenia persisting over a month. Medical management including increased doses of steroids in combination with cyclosporin failed to control hematochezia and thrombocytopenia. Immune thrombocytopenic purpura was suspected on the basis of normocellular marrow with a normal number of megakaryocytes. To treat uncontrolled colitis and steroid-refractory thrombocytopenia, total proctocolectomy with ileal pouch-anal anastomosis and splenectomy were performed. The patient was followed up for 10 months after surgery and was found to be in good health with a normal platelet count. Therefore, colectomy alone or in combination with splenectomy should be considered in cases of life-threatening ulcerative colitis complicated with steroid-refractory immune thrombocytopenic purpura. (Intest Res 2013;11:310-316)

Key Words: Ulcerative colitis; Immune thrombocytopenic purpura; Splenectomy; Colectomy

\section{서 론}

궤양성 대장염(ulcerative colitis)은 대장 및 직장의 점막층에 주로 발생하는 염증성 질환이며, 궤양성 대장염을 가진 환자 중 약 $42 \%$ 의 환자에게서 장외 합병증이 발생하는 것으로 알려져 있다. ${ }^{1}$ 궤양성 대 장염의 장외 합병증으로 관절 병변, 피부 병변, 간담도 질환과 혈액학

Received June 17, 2013. Revised July 20, 2013. Accepted August 5, 2013. Correspondence to Changhyun Lee, Department of Internal Medicine and Healthcare Research Institute, Healthcare System Gangnam Center, Seoul National University Hospital, $39 \mathrm{FL}$, Gangnam Finance Center, 152 Teheranro, Gangnam-gu, Seoul 135-984, Korea. Tel: +82-2-2112-5587, Fax: +82-22112-5794,E-mail:mdchlee@gmail.com

Financial support: None. Conflict of interest: None.
적 이상소견 등이 동반될 수 있으며, 그 중 혈액학적 이상소견으로는 철결핍성 빈혈(iron deficiency anemia), 용혈성 빈혈(hemolytic anemia)이 잘 알려져 있으나 드물게 혈소판 감소증(thrombocytopenia) 및 급성 골수성 백혈병(acute myelogenous leukemia) 등이 동반될 수 있는 것으로 보고되고 있다. ${ }^{2}$

면역성 혈소판 감소성 자반증(immune thrombocytopenic purpura) 은 당단백(glycoprotein)에 대한 자가항체에 의해 발생하는 질환이며 전신성 홍반성 루프스 등의 자가면역질환, 비호지킨 림프종이나 만성 림프구성 백혈병 등의 림프구 증식성 질환 및 바이러스 감염에 수반 하여 이차적으로 발생할 수 있다. ${ }^{3}$ 특히, 염증성 장질환에서 면역성 혈 소판 감소성 자반증의 발생은 크론병보다는 궤양성 대장염에 잘 동 반되는 것으로 보고되고 있으며, ${ }^{4}$ 국내에서도 ${ }^{5}$ 예 미만의 증례 보고

๑ Copyright 2013. Korean Association for the Study of Intestinal Diseases. All rights reserved.

This is an Open Access article distributed under the terms of the Creative Commons Attribution Non-Commercial License (http://creativecommons.org/licenses/by-nc/3.0)

which permits unrestricted non-commercial use, distribution, and reproduction in any medium, provided the original work is properly cited. 
가 있을 뿐이다. ${ }^{5,6}$ 면역성 혈소판 감소성 자반증이 동반된 궤양성 대 장염 환자에 대한 치료 방법은 아직 명확하게 확립되어 있지 않은 상 태이고, 증례의 수가 적기 때문에 병의 경과 및 치료와 예후에 대한 예측이 어렵다.

저자들은 궤양성 대장염 치료 중에 면역성 혈소판 감소성 자반증이 발생한 후 내과적 치료로 회복되었다가 11 년간의 관해기를 유지하던 중 궤양성 대장염의 급성악화와 함께 혈소판 감소증이 악화되어 수 술 치료를 시행한 1 예를 경험하였기에 문헌 고찰과 함께 보고하고자 한다.

\section{증 례}

37 세 남자 환자가 1 개월 전부터 시작된 혈변을 주소로 내원하였다. 13 년 전 혈변과 복통이 있어 구불창자내시경 검사를 시행하였고 궤양 성 대장염을 진단받았으며, 이후 설파살라진(sulfasalazine)을 사용하 면서 관해 상태를 유지하고 있었다. 환자는 2 년 후 하루에 6 회 이상 지속되는 혈변으로 응급실에 내원하였고, 당시 시행한 대장내시경에 서 항문연 $30 \mathrm{~cm}$ 에서 $80 \mathrm{~cm}$ 사이의 얕은 궤양성 병변들과 점막을 건드리면 쉽게 출혈하는 경향 및 점막하 혈관 분포의 소실 등이 관찰 되어 궤양성 대장염의 급성악화로 진단하였다. 금식 및 스테로이드 치 료를 시행하였으나 증상이 호전되지 않았고, 점차적으로 혈소판 수치 가 $149,000 / \mathrm{mm}^{3}$ 에서 $21,000 / \mathrm{mm}^{3}$ 까지 감소되었다. 이에 스테로이 드 불응성인 궤양성 대장염으로 진단하고 사이클로스포린(cyclosporin) 구조요법을 시행하였고, 이후 혈변 횟수가 감소하면서 혈소판 수 치가 함께 회복되었다. 이후 스테로이드는 천천히 감량하여 중단하였 고 증상호전 뒤 7달간 투약하였던 아자치오프린(azathioprine)도 중 단하였으며 설파살라진 단독요법으로 조절하면서 11년간 관해 상태 를 유지하였다. 내원 1달 전부터 혈변의 빈도가 하루에 10회 이상으로 증가되어 검사 및 치료를 위해 입원하였다. 과거력에서 당뇨, 고혈압, 폐결핵, 간염 등의 병력은 없었으며 가족력, 음주력 및 흡연력에서 특 이 소견은 없었다. 내원 당시 신체검진에서 활력징후는 혈압 104/73
$\mathrm{mmHg}$, 맥박 115 회/분, 호흡수 20 회/분, 체온 $37.4^{\circ} \mathrm{C}$ 이었다. 환자는 만성 병색을 보였고, 복부진찰에서 압통과 반발통은 없었으며 비장 은 촉지되지 않았다. 단순 흥부와 복부 방사선 검사에서 특이 소견은 보이지 않았으며, 말초혈액검사에서 혈색소 $11.6 \mathrm{~g} / \mathrm{dL}$, 헤마토크리 트 $34.8 \%$, 백혈구 4,900/ $\mathrm{mm}^{3}$ (호중구 $64 \%$, 림프구 $28 \%$, 단핵구 $7 \%$, 호산구 $0.1 \%$ ), 혈소판 $56,000 / \mathrm{mm}^{3}$ 으로 빈혈과 혈소판 감소증 을 보였다. 혈액화학검사에서는 $\mathrm{Na} 137 \mathrm{mEq} / \mathrm{L}, \mathrm{K} 4.2 \mathrm{mEq} / \mathrm{L}, \mathrm{Cl}$ $97 \mathrm{mEq} / \mathrm{L}$, calcium $8.4 \mathrm{mg} / \mathrm{dL}$ 이었으며, AST 9 IU/L, ALT $9 \mathrm{IU} /$ L, ALP $45 \mathrm{IU} / \mathrm{L}, \mathrm{LDH} 137 \mathrm{IU} / \mathrm{L}$, total bilirubin $0.4 \mathrm{mg} / \mathrm{dL}$, 총콜 레스테롤 $122 \mathrm{mg} / \mathrm{dL}, \mathrm{C}$-반응 단백 $2.62 \mathrm{mg} / \mathrm{dL}$, 적혈구 침강 속도 는 $46 \mathrm{~mm} /$ hour였다. 혈액응고검사에서 프로트롬빈시간 $94 \%$, 활성 화 부분트롬보플라스틴시간 22.9 초, 섬유소는 $269 \mathrm{mg} / \mathrm{dL}$ 로 정상범 위였으며, 간염바이러스 표지자 검사에서 $\mathrm{HBsAg}$ 음성, anti-HCV 음 성이었다. 궤양성 대장염의 합병증에 기인한 흡수장애를 감별하기 위 해 시행한 검사에서 엽산 $13.6 \mathrm{ng} / \mathrm{mL}$, 비타민 B12 1,968 pg/mL은

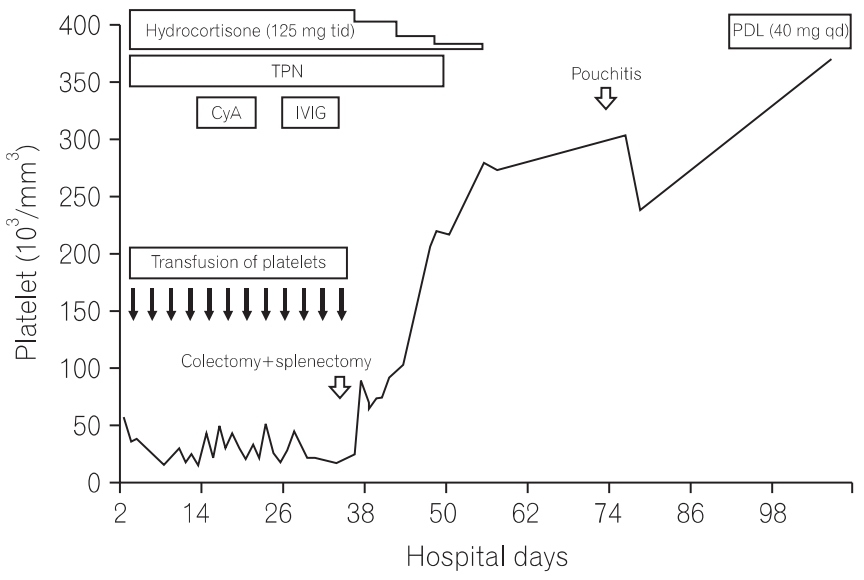

Fig. 2. Serial measurements of the platelet count with a second acute exacerbation of ulcerative colitis. CyA, cyclosporin A; IVIG, intravenous immunoglobulin; TPN, total parenteral nutrition; PDL, prednisolone.
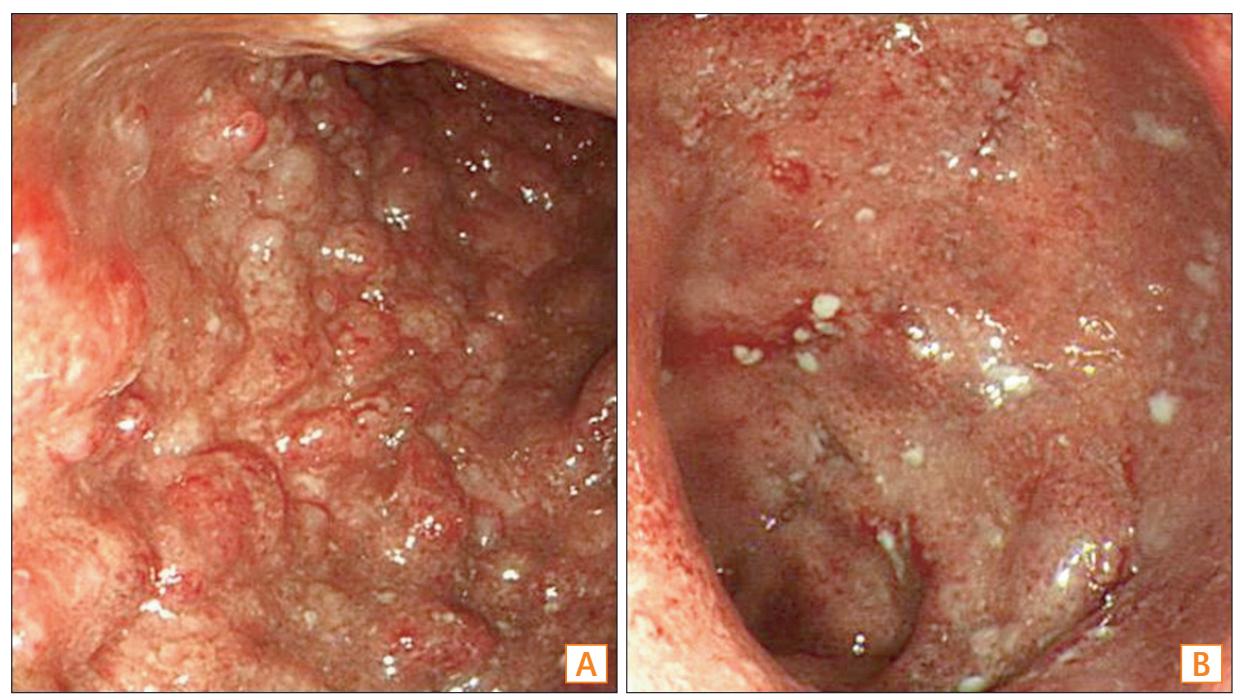

Fig. 1. Colonoscopic findings. (A) Severe edematous hyperemic changes in the mucosa and pseudopolyps. (B) Spontaneous bleeding with ulceration. 
정상범위였다.

입원 후 시행한 구불창자내시경 관찰범위 내에서 전장에 걸쳐 점막 의 과충혈 및 부종, 자발출혈이 동반되어 있었으며 광범위한 궤양 및 가성폴립이 관찰되었다(Fig. 1). 중증 궤양성 대장염으로 금식 및 총 정맥 영양을 시작하였고, 입원 1 병일부터 설파살라진의 복용을 중단 하고 하이드로코티손(hydrocortisone) $125 \mathrm{mg}$ 을 8시간 간격으로 2 주간 투약하였으나 혈변이 하루 10 회 이상 지속되었으며 혈소판 수치 도 $16,000 / \mathrm{mm}^{3}$ 까지 감소되었다. 스테로이드 불응성 궤양성 대장염 으로 판단하고 입원 14병일째부터 사이클로스포린을 투여했으나 혈 변과 혈소판 수치는 호전되지 않았다(Fig. 2). 혈소판 감소의 원인 규 명을 위해 시행한 항혈소판항체 검사, 항핵항체 검사, 항 HIV (human immunodeficiency virus) 항체 검사, 항DNA항체 검사, ACA (anticardiolipin $\mathrm{Ab} \mathrm{IgG}$ )와 LA (lupus anticoagulant) 검사는 음성이 었다. 혈액과 대변 배양 검사 및 C. difficile 독소 검사는 음성이었으 며 cytomegalovirus에 대한 면역조직화학염색도 음성이었다. 말초 혈 액 도말 검사에서 정구성 정색소성 빈혈 및 혈소판 수의 뚜렷한 감소 를 보였으며 복부 전산화단층촬영에서 비장비대는 관찰되지 않았다. 이에 혈소판 감소증의 정확한 원인 감별을 위해 골수 천자 및 생검

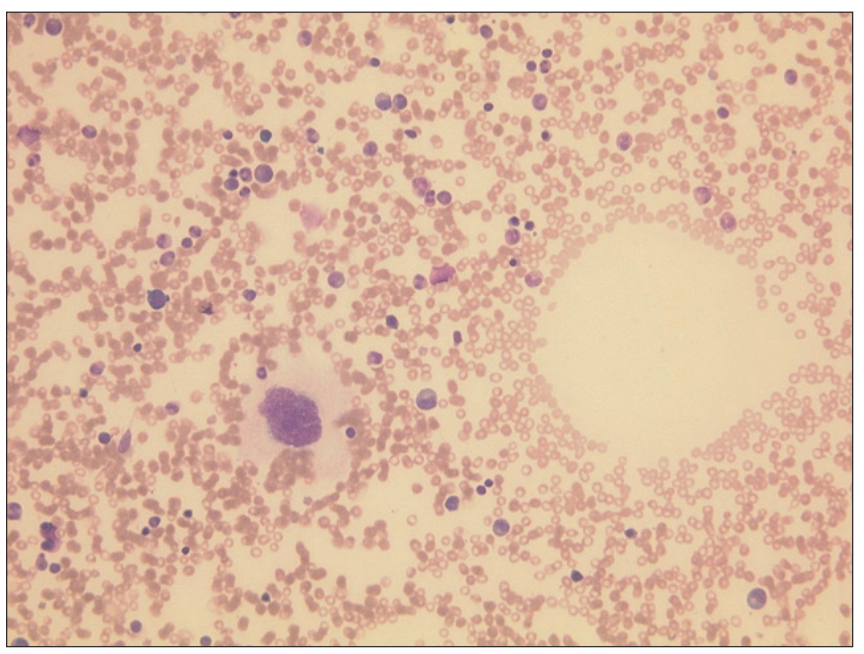

Fig. 3. Bone marrow biopsy findings. HetE staining at $20 x$, demonstrating normocellularity with a normal megakaryocyte count.
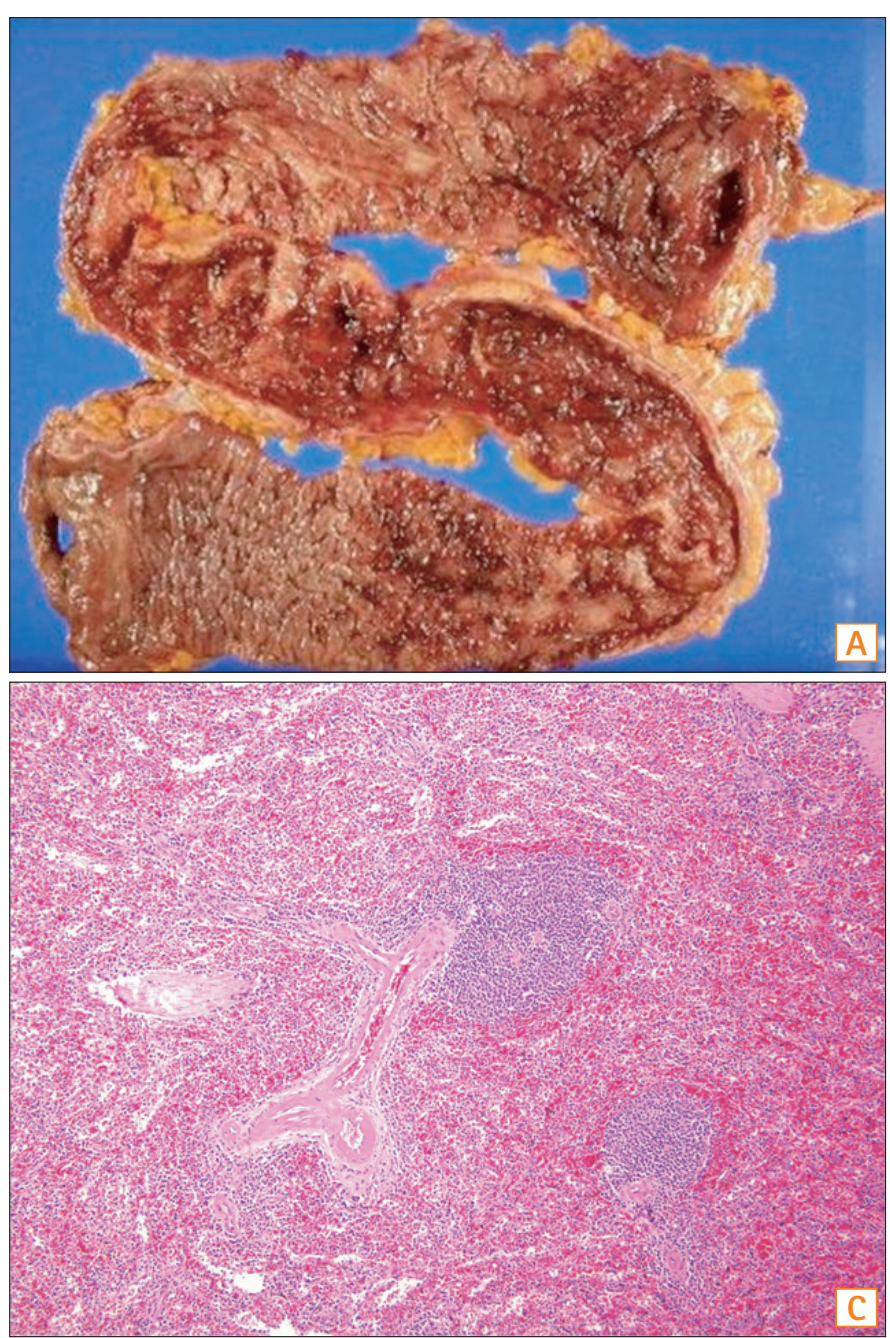

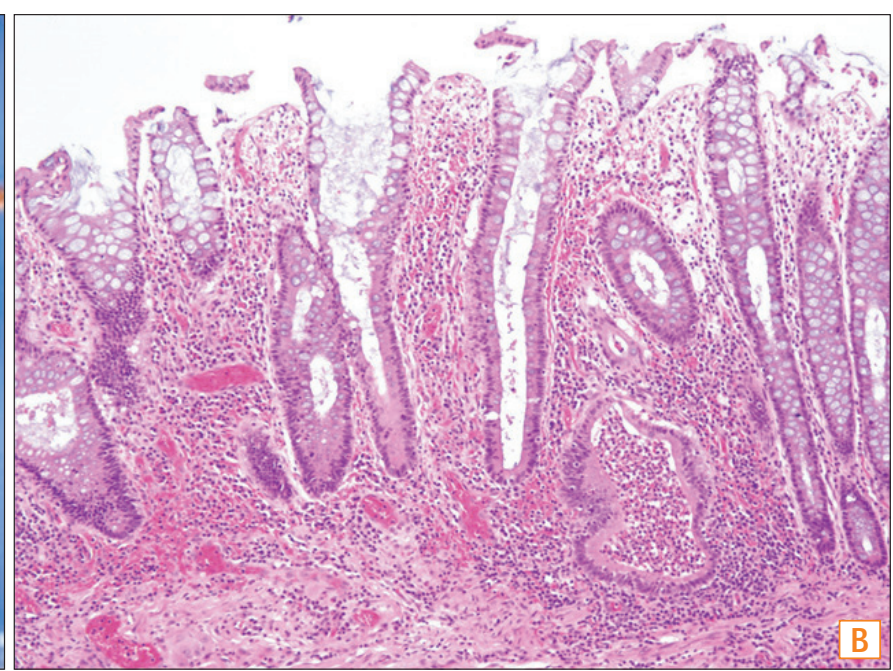

Fig. 4. Macroscopic and microscopic findings. (A) Macroscopic image of the colon showing pseudopolyps and inflammatory lesions. (B) Histopathological study of the colon biopsy specimen via HEtE staining at 100x demonstrating cryptitis and a crypt abscess with lymphoid aggregation in the submucosa. (C) Histopathological study of the spleen biopsy via HEtE staining at 100x demonstrating sinusoidal dilatation and congestion with histiocytic infiltration. 

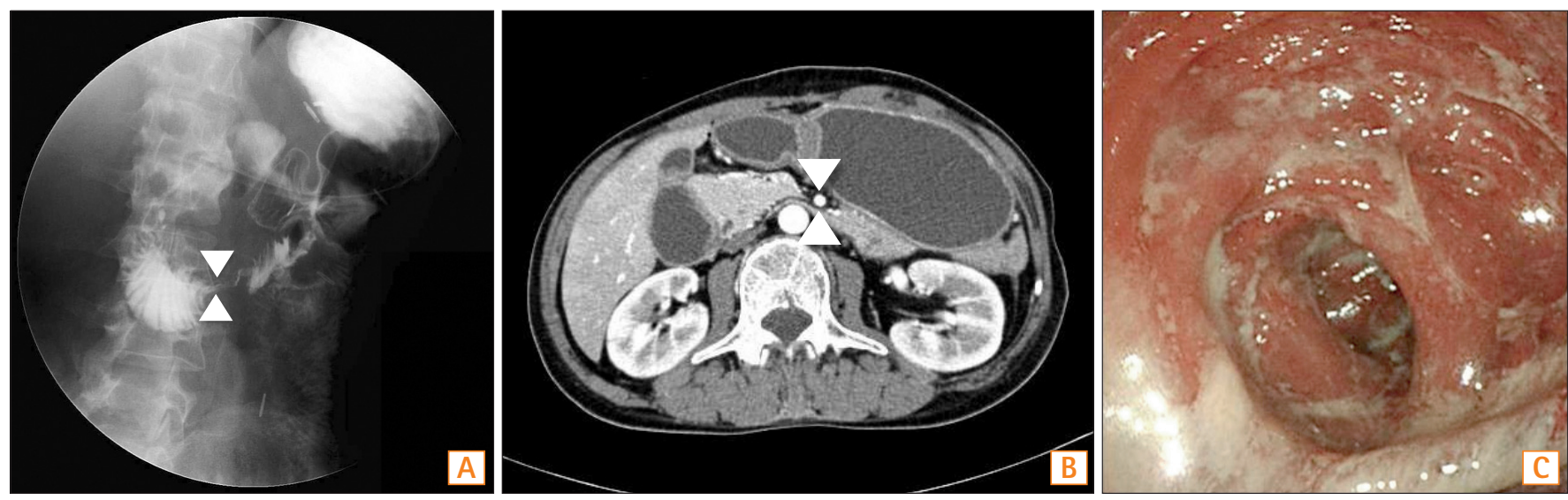

Fig. 5. (A) Gastrografin swallow depicting luminal narrowing of the third portion of the duodenum, and bird's beak appearance (arrowheads). (B) Abdominal CT showing duodenal compression with bird's beak appearance by the superior mesenteric artery (arrowheads) and the abdominal aorta. (C) Sigmoidoscopic findings suggesting hyperemic and edematous changes in the mucosa with a whitish exudate in the anal pouch.

을 시행하였다. 검사 결과 골수는 $71-80 \%$ 의 정상적인 세포충실도를 보였고, 골수세포와 조혈세포의 비는 1.9:1이었으며(정상 비: 2:1$4: 1$ ), 거대핵세포는 적절한 수를 보였다(Fig. 3). 상기 소견을 바탕으 로 스테로이드를 포함한 내과적인 치료에 실패한 중증 궤양성 대장염 및 동반된 면역성 혈소판 감소성 자반증으로 진단하고 수술 치료를 결정하였다. 수술 전 $1 \mathrm{~g} / \mathrm{kg}$ 의 정맥용 면역글로불린(intravenous immunoglobulin)을 이틀간 투여하여 혈소판 수치를 $91,000 / \mathrm{mm}^{3}$ 까지 상승시킨 후 전대장절제술과 회장낭-항문 문합술 및 비장절제술을 시행하였다. 수술 후 병리소견에서 음와염, 음와농양 및 점막하와 장 막하의 울혈과 응집된 림프구를 동반한 만성의 활동성 대장염과 직 장염이 관찰되었고(Fig. $4 \mathrm{~A}, \mathrm{~B})$, 비장은 조직구의 침윤을 동반한 굴 모양 혈관의 확장과 울혈이 관찰되었다(Fig. $4 \mathrm{C}$ ).

수술 후 7병일째 입원 중에 시행한 혈액검사에서 백혈구 8,970/ $\mathrm{mm}^{3}$, 혈색소 $12.0 \mathrm{~g} / \mathrm{dL}$, 혈소판 $130,000 / \mathrm{mm}^{3}$ 으로 혈소판 수치 는 회복되었고, 적혈구 침강 속도 $5 \mathrm{~mm} /$ hour, C-반응 단백은 0.18 $\mathrm{mg} / \mathrm{dL}$ 으로 감소하였다(Fig. 2). 그러나 구역질과 구토가 반복되면 서 식이 진행이 되지 않아 가스트로그라핀(gastrografin)을 이용한 상 복부 조영술(Fig. 5A) 및 복부 전산화단층촬영(Fig. 5B)을 시행하였 다. 상복부 조영술에서 십이지장 3 번째 부위의 내강이 좁아져 있어 조 영제의 통과가 지연되어 있었고, 복부 전산화단층촬영에서 상장간막 동맥과 대동맥 사이 십이지장의 2 번째 중간부위에서 위와 십이지장 의 뚜렷한 팽창이 관찰되어, 오랜 기간의 금식과 회장낭-항문 문합술 로 인한 상장간막 동맥 증후군(superior mesenteric artery syndrome) 으로 진단되었다. 이에 총정맥영양을 통해 영양상태를 호전시키고, 체 중이 증가되면서 증상이 호전되어 수술 후 20 병일째 퇴원하였다.

퇴원 2주일 후 구토 및 설사로 다시 내원하였고 구불창자내시경 검 사에서 항문주머니 전반에 걸쳐 점막이 충혈되고 부어있었으며 부분 적으로 흰색의 삼출물로 덮인 것이 관찰되었고, 조직검사에서 궤양 이 동반된 만성 활동성 주머니염으로 진단되었다(Fig. $5 \mathrm{C}$ ). 복부 전 산화단층촬영에서 상장간막 동맥 증후군에 의한 십이지장의 폐쇄 가 지속되는 소견을 보였다. 당시 시행한 혈액 검사에서 $\mathrm{C}$-반응 단백
은 $11.79 \mathrm{mg} / \mathrm{dL}$, 적혈구 침강 속도는 $43 \mathrm{~mm} /$ hour으로 상승되어 있 었고 혈소판 수치는 $310,000 / \mathrm{mm}^{3}$ 로 정상범위였다. 이에 위공장문 합술을 고려하였으나 환자가 거부하여 비수술 치료를 시행하기로 하 였다. 총정맥 영양 및 스테로이드를 투여하였고 비장관(naso-jejunal tube)을 통한 경관 식이를 진행하면서 전신 상태가 호전되었고, 이후 경구를 통한 식이도 문제 없이 진행되어 입원 32 병일째 퇴원하였다. 환자는 이후 스테로이드를 중단하였으며, 6 개월 후 장루복원술을 시 행받았다. 현재 수술 후 10 개월째로 투약 없이 외래 추적 관찰 중으 로, 아직까지 혈액검사에서 혈소판 감소증의 재발은 보이지 않고 있 다.

\section{고 찰}

궤양성 대장염에 동반된 면역성 혈소판 감소성 자반증은 1964년 Edwards와 Truelove ${ }^{7}$ 가 처음 기술한 이래로 산발적으로 보고되고 있 으나, 상관관계 및 발생기전은 아직 명확하게 알려지지 않았다. ${ }^{6}$ 하지 만 최근에는 궤양성 대장염으로 인해 장관의 투과성이 증가되고 장 관 내 세균의 항원과 반응한 항체가 혈액으로 유입되면서, 이차적으 로 전신적인 면역반응을 일으켜 면역성 혈소판 감소성 자반증이 발생 한다는 가설이 제시되고 있다. ${ }^{8}$ 면역성 혈소판 감소성 자반증이 궤양 성 대장염과 우연히 동반되어 발생한 것인지 궤양성 대장염의 합병증 인지에 대해서는 아직 논란이 있는 상태이다.

그러나 Zlatanic 등 ${ }^{9}$ 이 염증성 장질환과 특발성 혈소판 감소성 자반 증을 가지는 환자들을 대상으로 분석한 결과, 염증성 장질환이 진단 된 수 일에서 수 년 이후 혈소판 감소증이 발생하였으며 특히 장질환 이 활성화될 경우 혈소판 감소가 악화되었다. 이 증례에서도 궤양성 대장염 진단 2년 후 급성악화와 함께 혈소판 감소증이 발생하였으나 사이클로스포린 치료를 통해 궤양성 대장염이 호전되면서 혈소판 수 치도 회복되어 11 년간 관해를 유지하고 있다가, 다시 궤양성 대장염이 악화되면서 혈소판 수치가 감소하는 궤양성 대장염의 질병 활성도와 혈소판 수치의 역 상관관계를 보여주었다. 
5-아미노살리실산(5-aminosalicylic acid)은 직접적인 골수억제를 통해 혈소판 감소증을 일으키나 약물 중단 후 혈소판 수치는 회복되 는 것으로 알려져 있고, ${ }^{10}$ 궤양성 대장염의 치료 중 발생하는 면역성 혈소판 감소성 자반증의 경우 이러한 치료 약제로 인한 혈소판 감소 증을 배제하는 것이 중요하다. 이번 증례에서도 입원 1 병일부터 설파 살라진의 복용을 중단하고 4 주 이상이 지났음에도 불구하고 혈소판 수의 증가를 관찰할 수 없었고, 이에 정확한 원인감별을 위해 시행한 골수검사에서 정상적인 세포충실도 및 세포분획을 보였으며 거핵구 수도 정상 범위여서 약물에 의한 골수억제보다는 면역성 혈소판 감소 성 자반증에 합당하다고 판단되었다. 이번 증례에서는 이외에도 이차 성 혈소판 감소증의 원인으로 알려져 있는 만성간질환, 비장종대, 전 신성 홍반성 루푸스와 같은 자가면역질환, HIV 및 cytomegalovirus 등의 바이러스 감염, 영양 결핍 등을 감별하였다. 환자는 간질환의 위 험요인을 가지고 있지 않으며 간기능 검사와 영상검사에서 이상소견 이 없어 만성 간질환 및 비장종대를 배제할 수 있었다. 또한 입원 중 시행한 자가면역항체 검사와 바이러스 및 세균 감염에 대한 검사는 모두 음성이었고, 엽산과 비타민 B12 수치도 감소되지 않아 흡수장애 로 인한 혈소판 감소증을 배제할 수 있었다.

외국의 보고들과 이번 증례를 종합해 보았을 때 궤양성 대장염의 악화에 동반된 혈소판 감소증의 경우 면역성 혈소판 감소성 자반증을 반드시 감별해야 할 것으로 생각한다.

지금까지 국내에서 보고되거나 MEDLINE (PubMed)을 통해 검색 및 확인 가능한 증례보고의 내용을 Table $1^{5,6,8,11-15}$ 에 정리하였다. 궤 양성 대장염과 면역성 혈소판 감소성 자반증 모두 스테로이드 사용이
효과적인 것으로 알려져 있지만, 궤양성 대장염에 면역성 혈소판 감소 성 자반증이 동반되는 경우 대부 분 스테로이드만으로 완전 관해를 보 이지 못하며 혈소판 수치 회복에 만족스럽지 않은 결과를 보이는 것 으로 알려져 있다. ${ }^{6}$ 궤양성 대장염의 경우 스테로이드를 사용한 일차 적인 내과 치료에 실패하는 경우 구조요법으로 사이클로스포린 혹은 인플리시맙(infliximab)의 사용을 고려할 수 있으며, 이 경우 인플리 시맙과 사이클로스포린의 효과는 비슷한 것으로 알려져 있다. ${ }^{16}$ 하지 만 인플리시맙의 부작용 중 혈소판 감소증이 보고된 바 있으며, ${ }^{17}$ 이번 증례에서는 11 년 전 궤양성 대장염의 급성악화 시에 사이클로스포린 구조요법에 반응이 있었기 때문에 인플리시맙을 사용하지 않고 사이 클로스포린을 다시 투여하였으나 혈변과 혈소판 수치는 회복되지 않 았다.

내과적인 치료에 반응을 보이며 대장절제술이나 비장절제술을 시 행 받지 않은 환자는 13 예 중 3예(23.1\%)에 불과하였다. 스테로이드 에 부분적인 관해를 보인 1예와 스테로이드에 반응이 없었으나 면역 글로불린에 반응을 보인 2예 및 대장절제술을 고려하였으나 뇌출혈 로 사망한 1예를 제외한 나머지 9예들은 최종적으로 수술 치료를 시 행받았다. 이 경우 수술방법에 대한 가이드라인이나 비교연구는 없으 나 증례보고들을 살펴보면 궤양성 대장염이 심하지 않은 경우 비장절 제술만 시행하고, 궤양성 대장염이 심한 경우 대장절제술만 시행하거 나 대장절제술과 비장절제술을 함께 시행하였다. ${ }^{6}$ Table 1을 보면 비 장절제술 단독은 4 예, 대장절제술 단독은 3 예, 대장절제술과 비장절 제술을 동시에 시행받은 경우는 2 예였다. 이번 증례에서는 대장절제 술과 비장절제술을 동시에 시행하였고 이후 혈변이 호전되었으며 혈

Table 1. A Summary of Reported Cases of Ulcerative Colitis and Immune Thrombocytopenic Purpura

\begin{tabular}{|c|c|c|c|c|c|c|c|c|c|}
\hline Case & $\begin{array}{c}\text { Age }(y r) / \\
\text { sex }\end{array}$ & $\begin{array}{l}\text { Duration of UC } \\
\text { before ITP }\end{array}$ & $\begin{array}{l}\text { Platelet } \\
\left(/ \mathrm{mm}^{3}\right)\end{array}$ & $\begin{array}{c}\text { WBC (PMN) } \\
\left(/ \mathrm{mm}^{3}\right)\end{array}$ & Steroid & Cyclosporin & IVIG & Splenectomy & Colectomy \\
\hline \multirow[t]{2}{*}{ Nam et al. ${ }^{5}$} & $39 / F$ & 1 month & 26,000 & $700(57.0 \%)$ & - & & Done & ++ & Done \\
\hline & $65 / F$ & Simultaneous & 25,000 & & + & & & & \\
\hline Park et al. ${ }^{6}$ & $39 / M$ & 18 months & 20,000 & 9,400 (82.2\%) & - & & - & ++ & \\
\hline \multirow[t]{3}{*}{ Yoshida et al. } & $65 / F$ & 19 years & 22,000 & & - & & ++ & & \\
\hline & $27 / M$ & 1 year & 10,000 & & - & & ++ & & \\
\hline & $42 / F$ & 14 years & 15,000 & & - & & & ++ & \\
\hline Hisada et al. ${ }^{11}$ & $36 / \mathrm{M}$ & 5 months & 17,000 & 5,000 (48.5\%) & - & & - & & ++ \\
\hline \multirow[t]{2}{*}{ Mizuta et al. ${ }^{12}$} & 19/M & 2 months & 37,000 & & + & & & & ++ \\
\hline & $51 / M$ & 2 months & 31,000 & & - & & & & \\
\hline Kodaira et al. ${ }^{13}$ & $23 / \mathrm{M}$ & Simultaneous & 3,000 & & - & & & ++ & \\
\hline Dooley et al. ${ }^{14}$ & $63 / \mathrm{M}$ & Simultaneous & 10,000 & & - & & & ++ & \\
\hline Varderili et al. ${ }^{15}$ & $20 / \mathrm{M}$ & 6 years & 33,000 & & + & & & & ++ \\
\hline Present case & $39 / \mathrm{M}$ & 13 years & 16,000 & $4,900(76.0 \%)$ & - & - & - & ++ & Done \\
\hline
\end{tabular}

ITP, immune thrombocytopenic purpura; WBC, white blood cells; PMN, polymorphonuclear; IVIG, intravenous immunoglobulin; F, female; $M$, male; $(++)$, complete response, increase in the platelet count to more than $120,000 / \mu \mathrm{L}$ persisting for the duration of observation; $(+)$, partial response, an increase in the platelet count to more than $50,000 / \mu \mathrm{L}$ persisting for the duration of observation; (-), no response, no increase in the platelet count to more than $50,000 / \mu \mathrm{L}$ persisting for the duration of observation; Done, surgery or drug administration performed but data on evaluation of platelet response not available. 
소판 수치도 정상으로 회복되었다. 하지만, 면역성 혈소판 감소성 자 반증이 동반된 궤양성 대장염에서 대장절제술만으로도 혈소판 수치 가 호전된 증례도 보고되고 있다. ${ }^{11}$ 또한 Kathula 등 ${ }^{18}$ 과 Bauer 등 ${ }^{19}$ 은 비장절제술에도 호전이 없는 면역성 혈소판 감소성 자반증이 동반 된 궤양성 대장염 환자에서 대장절제술을 시행한 이후 혈소판 감소 증이 호전된 증례를 보고하였다. 이러한 증례보고 결과들을 고려했을 때 대장절제술 단독도 면역성 혈소판 감소성 자반증이 동반된 궤양성 대장염의 치료 방법 중 하나로 고려해 볼 수 있다. 하지만, Yong 등 ${ }^{20}$ 은 젊은 중증의 궤양성 대장염 환자에서 대장절제술 후 소장의 폐색 과 함께 면역성 혈소판 감소증이 병발했던 예를 보고한 바 있어 면역 성 혈소판 감소성 자반증과 궤양성 대장염이 동반된 환자에게 적절한 수술법에 대해서는 개별화된 전략 및 추가적인 전향적인 연구가 필요 할 것으로 생각된다.

이번 증례에서는 수술 이후 스테로이드 치료가 필요할 정도의 주머 니염이 발생함에도 불구하고 혈소판 감소는 동반되지 않았다. 환자는 광범위한 침범, 중증의 대장염, 젊은 나이의 발병, 장외증상 동반, 비 흡연력 등의 위험요소가 동반된 주머니염의 고위험군이었다. 수술 후 장루복원을 하지 않은 상태에서 스테로이드 치료가 필요할 정도의 주 머니염이 발생하였고, 당시 C-반응 단백은 $11.79 \mathrm{mg} / \mathrm{dL}$, 적혈구 침 강 속도는 $43 \mathrm{~mm} /$ hour로 상승되어 있었다. Yong 등 ${ }^{20}$ 의 보고와 장 내 항원 유입에 의한 혈소판 감소증의 발생기전을 고려해보면 대장절 제술 후 회장낭 부위의 염증으로 인해 혈소판 감소가 발생할 수 있었 으나 비장절제술을 통해 예방할 수 있었다고 생각된다.

이번 증례에서 수술 후 혈소판 수치는 회복되었으나, 구역질과 구 토가 반복되면서 식이진행이 잘 되지 않았으며, 상복부 조영술 및 복 부 전산화단층촬영을 통해 상장간막동맥 증후군을 진단받았다. 궤양 성 대장염 환자에서 수술 전 장기간 금식을 유지하는 경우 체중감소 와 함께 장간막 지방이 감소하며, 이러한 상태에서 회장낭-항문 문합 술을 시행받는 경우 상장간막 동맥의 기시부 각이 감소하게 되면서 십이지장을 압박하여 상장간막동맥 증후군이 발생할 수 있다. 이번 증례에서도 수술 전 스테로이드 및 사이클로스포린 치료와 백신 투약 으로 인하여 금식기간이 길어지고 회장낭-항문 문합술을 시행하면서 상장간막 동맥 증후군의 발생위험이 높아진 것으로 보인다. 따라서, 중증의 궤양성 대장염에 동반된 면역성 혈소판 감소성 자반증 환자의 경우 초기 스테로이드 치료에 반응이 없으면 비장절제술을 포함한 수 술 가능성에 대비하여 예방접종 및 혈소판 감소증에 대한 검사를 조 기에 시행하고 적극적인 영양공급을 통해 체중을 유지하는 것이 수술 후 합병증 감소에 도움이 될 것이다.

저자들은 궤양성 대장염 치료 중에 혈소판 감소증이 발생한 후 내 과 치료로 회복되었다가 11 년 간의 관해기를 유지하던 중 궤양성 대 장염의 급성악화와 함께 혈소판 감소증이 악화되어 궤양성대장염과 동반된 면역성 혈소판 감소성 자반증으로 확진하고 수술 치료를 시행 한 1 예를 경험하였기에 문헌 고찰과 함께 보고하고자 한다.

\section{REFERENCES}

1. Ozdil S, Akyüz F, Pinarbasi B, et al. Ulcerative colitis: analyses of
116 cases (do extraintestinal manifestations effect the time to catch remission?). Hepatogastroenterology 2004;51:768-770.

2. Imagawa M. Extra-intestinal complications of ulcerative colitis: hematologic complication. Nihon Rinsho 1999;57:2556-2561.

3. Bussel JB. Autoimmune thrombocytopenic purpura. Hematol Oncol Clin North Am 1990;4:179-191.

4. Gumaste V, Greenstein AJ, Meyers R, Sachar DB. Coombs-positive autoimmune hemolytic anemia in ulcerative colitis. Dig Dis Sci 1989;34:1457-1461.

5. Nam SW, Yang SK, Kim JC, et al. Immune thrombocytopenia purpura and neutropenia associated with ulcerative colitis. Korean J Gastroenterol 1999;33:135-141.

6. Park BH, Kim HJ, Chang YW, et al. Immune thrombocytopenic purpura in a patient with preexisting ulcerative colitis: a case report. Korean J Gastrointest Endosc 2002;24:44-48.

7. Edwards FC, Truelove S. Course and prognosis of ulcerative colitis: Part III complications. Gut 1964;5:1-15.

8. Yoshida EM, Chaun H, Freeman HJ, Whittaker JS, Galbraith PF. Immune thrombocytopenic purpura in three patients with preexisting ulcerative colitis. Am J Gastroenterol 1996;91:12321235.

9. Zlatanic J, Korelitz BI, Wisch N, et al. Inflammatory bowel disease and immune thrombocytopenic purpura: is there a correlation? Am J Gastroenterol 1997;92:2285-2288.

10. Farrell RJ, Peppercorn MA, Fine SN, Michetti P. Mesalamine-associated thrombocytopenia. Am J Gastroenterol 1999;94:23042306.

11. Hisada T, Miyamae Y, Mizuide M, et al. Acute thrombocytopenia associated with preexisting ulcerative colitis successfully treated with colectomy. Intern Med 2006;45:87-91.

12. Mizuta Y, Isomoto H, Kadokawa Y, et al. Immune thrombocytopenic purpura in patients with ulcerative colitis. J Gastroenterol 2003;38:884-890.

13. Kodaira M, Hanai H, Kajimura M, et al. Further evidence that exacerbation of ulcerative colitis causes the onset of immune thrombocytopenia: a clinical case. Am J Gastroenterol 1999;94:1408-1410.

14. Dooley DP, Mills GM, Spiva DA. Immune thrombocytopenia and ulcerative colitis. South Med J 1986;79:1044-1045.

15. Varderili E, Sariçam T, Aslan V, Gülbaş Z. Resolution of immune thrombocytopenic purpura after colectomy for ulcerative colitis. Turk J Gastroenterol 2003;14:270-272.

16. Laharie D, Bourreille A, Branche J, et al; Groupe d'Etudes Thérapeutiques des Affections Inflammatoires Digestives. Ciclosporin versus infliximab in patients with severe ulcerative colitis refractory to intravenous steroids: a parallel, open-label randomised controlled trial. Lancet 2012;380:1909-1915.

17. Vidal F, Fontova R, Richart C. Severe neutropenia and thrombocytopenia associated with infliximab. Ann Intern Med 2003;139:W-W63.

18. Kathula SK, Polenakovik H, el-Tarabily M, Polenakovik S. Complete resolution of refractory immune thrombocytopenic purpura after colectomy for ulcerative colitis. Int J Clin Pract 2001;55:647-648. 
19. Bauer WM, Litchtin A, Lashner BA. Can colectomy cure immune thrombocytopenic purpura in a patient with ulcerative colitis? Dig Dis Sci 1999;44:2330-2333.
20. Yong S, Persad R, Dower N, Lees G, El-matary W. Idiopathic thrombocytopenic purpura after colectomy for pediatric ulcerative colitis. Inflamm Bowel Dis 2008;14:1313-1315. 